\title{
Design of acetylcholinesterases for biosensor
}

\section{applications}

Holger Schulze, Sandra Vorlová, Francois Villatte, Till T. Bachmann, Rolf D. Schmid *

"Corresponding author:

Institute of Technical Biochemistry

University of Stuttgart

Allmandring 31

D-70569 Stuttgart, Germany

E-mail: Rolf.D.Schmid@itb.uni-stuttgart.de 


\section{Abstract}

In recent years, the use of acetylcholinesterases (AChEs) in biosensor technology has gained enormous attention, in particular with respect to insecticide detection. The principle of biosensors using AChE as a biological recognition element is based on the inhibition of the enzyme's natural catalytic activity by the agent that is to be detected. The advanced understanding of the structure-function-relationship of AChEs serves as the basis for developing enzyme variants, which, compared to the wild type, show an increased inhibition efficiency at low insecticide concentrations and thus a higher sensitivity. This review describes different expression systems that have been used for the production of recombinant AChE. In addition, approaches to purify recombinant AChEs to a degree that is suitable for analytical applications will be elucidated as well as the various attempts that have been undertaken to increase the sensitivity of AChE to specified organophosphates and carbamates using sidedirected mutagenesis and employing the enzyme in different assay formats.

Key Words: Genetically engineered acetylcholinesterase, Sensitivity, Biosensor, Organophosphates, Carbamates, Expression Systems 


\section{Introduction}

Acetylcholinesterase (AChE, EC 3.1.1.7) plays a key role in cholinergic transmission by catalysing the rapid hydrolysis of the neurotransmitter acetylcholine into acetate and choline (Rosenberry, 1975). The enzyme effectively terminates the chemical impulse at rates that are similar to a diffusion-controlled process allowing a rapid and repetitive response (Bazelyansky et al., 1986). Inhibitors of AChE, such as organophosphates and carbamates, interfere with this process and may lead to a severe impairment of nerve functions or even death. Therefore, insect AChE is the biological target of predominant insecticides used in agriculture. AChE inhibitors are useful but at the same time pose severe environmental and health risks (Millard and Broomfield, 1995). Consequently, there is a growing interest in faster and more sensitive detection systems. Methods traditionally used for the detection of insecticides are based on gas chromatography (GC) or high performance liquid chromatography (HPLC) coupled with mass selective detectors (MSD) (Martinez et al., 1992; Pylypiw, 1993). As an alternative, acetylcholinesterase (AChE) inhibition tests, and the AChE-biosensors in particular, have been shown to be suitable for the detection of insecticides. The pioneering work of George G. Guilbault, focused on cholinesterase purification and inhibitor analysis (Guilbault et al., 1970a; Guilbault et al., 1970b; Guilbault et al., 1970c), immobilization (Guilbault and Das, 1970) and assay development (Guilbault and Kramer, 1965; von Storp and Guilbault, 1972; Gibson and Guilbault, 1975; Guilbault and Iwase, 1976; Van Sant, 1986; Guilbault and Schmid, 1991; Huang et al., 1993), has paved the way for many other groups involved in the development of different biosensor formats for neurotoxin detection. Selected examples are shown in Table 1. 
AChE-based biosensors have a major drawback: they give a sum parameter of AChE-inhibition without any qualitative or quantitative information about the individual analytes, i.e. different AChE-inhibiting insecticides cannot be measured selectively. One approach to solve this problem involves the application of multisensor arrays that are combined with the data processing of artificial neural networks. Genetically engineered cholinesterase variants with specific and high inhibition constants for the desired analytes are required for the compound-specific multianalyte detection.

The resolution of the three dimensional structure of Torpedo californica AChE using x-ray refraction (Sussman et al., 1991), the elucidation of the structure-functionrelationship of AChEs probed by site-directed mutagenesis (Vellom et al., 1993; Ashani et al., 1995; Faerman et al., 1996) and the development of efficient expression systems for the production of larger amounts of recombinant AChEs all contributed to the use of this enzyme in analytical applications. Specific AChEs with an increased sensitivity towards different inhibitors could be developed by sidedirected mutagenesis and be used successfully for the detection of minute quantities of pesticides in environmental and food samples.

\section{Functional expression of recombinant AChEs}

A prerequisite for the commercialisation of biosensors is the availability of large amounts of extremely pure, functional and stable enzyme samples at low costs. AChE can be purified from human or animal blood or from the electric organ of the electric eel. These sources are, however, limited and the purification is both time and cost intensive. To overcome this problem, AChEs of different origin have been cloned and functionally expressed in several systems. Active and correctly processed Bungarus fasciatus (Cousin et al., 1996a), rat (Legay et al., 1993), Torpedo 
marmorata (Duval et al., 1992b) and Electrophorus electricus (Simon and Massoulie, 1997) AChEs have been produced in COS cells, rat AChE in RBL cells (Coussen et al., 1995) and human AChE in HEK 293 cells (Velan et al., 1991b; Kronman et al., 1992). However, these studies focus mainly on the development of an efficient mammalian cell system to provide an experimental tool for the detailed analysis of the catalytic mechanisms and structural properties of AChEs rather than on high yields of purified AChEs. The biosynthetic processes that lead to numerous different AChE forms have also been intensively investigated in these cell systems. The amounts of expressed protein in mammalian cells, however, were very low (Table 2). Production costs and the production of the enzymes on a larger scale prove to be major obstacles. AChEs from Torpedo californica (Radic et al., 1992), Drosophila melanogaster (Chaabihi et al., 1994; Estrada-Mondaca et al., 1998) and rat brain (Mionetto et al., 1997) could be actively expressed in satisfactory amounts in a baculovirus-insect cell system (Table 2). The baculovirus system has severe limitations with respect to the production of larger amounts of protein, but seems to be very suitable for producing mutant recombinant AChEs. Attempts to express functional human (Fischer et al., 1993) or rat brain (Heim et al., 1998) AChE in Escherichia coli failed because the expressed enzyme was accumulated in inclusion bodies as an inactive protein. Only a small amount of active AChE could be recovered by refolding and oxidation procedures. In addition, the recombinant human enzyme was unstable (Fischer et al., 1993). Recently, Mor et al. described the expression of human AChE in transgenic tomato plants (Mor et al., 2001). Active and stable AChE, which retains the kinetic characteristics of the native human enzyme, could be enriched in tomato plants and isolated from leaves and fruit. The functional expression and secretion into the medium of rat brain (Morel and Massoulie, 1997; Heim et al., 1998), Bungarus fasciatus (Morel and Massoulie, 1997) and 
Nippostrongylus brasiliensis (Hussein et al., 1999) AChE could be achieved using the methylotrophic yeast Pichia pastoris and the ability of Pichia pastoris to synthesise and correctly process vertebrate AChEs could be shown. Further optimisation of the cultivation conditions and the possibility of performing fed-batch or continuous fermentation on a large scale renders Pichia pastoris one of the most promising expression systems with regard to the low-cost and high-yield production of recombinant AChEs. In addition, a rapid and efficient assay to screen active Pichia pastoris transformants using indoxylacetate as substrate was recently proposed (Villatte et al., 2001).

Different strategies to enhance the expression of AChE on the gene level were pursued. One strategy involves the examination of the expression of recombinant rat or Bungarus AChE in Pichia pastoris by exchanging the native signal peptides for yeast signal peptides or by introducing propeptides which do usually not exist in AChE (Morel and Massoulie, 1997). A second approach arose from the observation that highly homologous AChEs from different species are produced at markedly different levels in the same expression systems (Cousin et al., 1996a; Morel and Massoulie, 1997). Rat/Bungarus and Bungarus/rat chimeras were expressed in COS cells (Morel and Massoulie, 2000) in order to elucidate the causes of the variability in the expression levels of different enzymes. 


\section{Purification of recombinant AChE}

After the expression of recombinant $\mathrm{AChE}$ and especially $\mathrm{AChE}$ mutants in heterologous systems it is important to purify the enzyme rapidly in order to characterise its features and estimate its applicability in a biosensor. Two approaches are usually applied for the purification of the enzymes: ion exchange chromatography (Estrada-Mondaca and Fournier, 1998; Heim et al., 1998) and affinity chromatography (Estrada-Mondaca and Fournier, 1998; Heim et al., 1998; Villatte et al., 1998; Villatte et al., 2000) based on the chemical modification of the support with reversible AChE inhibitors (Massoulie and Bon, 1976; Ralston et al., 1983) or on the addition of a His-tag to the enzyme (Estrada-Mondaca and Fournier, 1998; Heim et al., 1998; Hussein et al., 1999; Hussein et al., 2000).

Estrada-Mondaca and Fournier combined affinity chromatography (using procainamide as ligand) with anionic-exchange chromatography for the purification of Drosophila melanogaster AChE (DmAChE) after expression in baculovirus-infected cells (Estrada-Mondaca and Fournier, 1998). The use of a diethylaminoethyl (DEAE)Sepharose column after affinity purification allowed the separation of AChE from proteases that are co-extracted with the AChE. The use of a His-tagged variant of DmAChE for metal chelating affinity chromatography led to an extremely pure enzyme (purity $>95 \%$ ) that did not exhibit any protease activity. After expression in Drosophila Schneider Line2 cells, Harel et al. purified recombinant DmAChE in two purification cycles using acridinium resin (Rosenberry and Scoggin, 1984; Harel et al., 2000). In the first purification round, purified DmAChE was eluted from the column by ligand competition using decamethonium with Triton X-100; in the second round no Triton X-100 was used. Dialysis was employed to remove decamethonium. Because the elution with decamethonium only yielded a recovery rate of $1 \%$ of the 
applied AChE-activity, Heim et al. eluted recombinant rat brain AChE (RbAChE) expressed in E. coli using acetylcholine iodide instead of decamethonium (Heim et al., 1998). Two purification cycles resulted in a specific activity of $253 \mathrm{U} / \mathrm{mg}$. Purification of His-tagged AChE on a Ni-NTA affinity column yielded $8.4 \mathrm{mg}$ purified enzyme. This amount corresponded to a calculated recovery yield of approximately $90 \%$. Hussein et al. purified recombinant AChE from the parasitic nematode Nippostrongylus brasiliensis with acridium affinity chromatography and by nickelchelating affinity chromatography (Hussein et al., 1999). Acridium affinity chromatography yielded a considerably lower specific activity of the native enzyme (685 $\mathrm{U} / \mathrm{mg})$ than nickel-chelating chromatography of the recombinant enzyme (2080 $\mathrm{U} / \mathrm{mg}$ ). This was attributed to the residual binding of decamethonium to the native enzyme.

\section{Protein engineering of $\mathrm{AChE}$}

\subsection{Sequence and structure}

AChEs have a remote sequence similarity with other esterases, especially butyrylcholinesterases, carboxylesterases and lipases (Cousin et al., 1996b). Comprehensive information on sequence and structure of AChEs is provided by the well-maintained ESTHER database (Cousin et al., 1996b) at http://www.ensam.inra.fr/cholinesterase.

Three residues (catalytic triad) are essential for the enzyme's activity: serine, histidine and glutamate (Rosenberry, 1975; Duval et al., 1992a). This active site is located near the bottom of a $20 \AA$ deep, narrow gorge that is lined with 14 conserved aromatic amino acids (Sussman et al., 1991; Saxena et al., 1997). Substrates and inhibitors bind to three distinct binding sites (Radic et al., 1993): 1. the size of the acyl 
pocket (F295, R296, F297, V300 in mouse AChE) determines substrate specificity (butyrylcholine vs acetylcholine) and mediates sensitivity towards the transition-state analogous inhibitors (organophosphates and carbamates) of different size; 2 . the choline binding site (W86, E202, Y337) binds specifically to the substrate choline group and is blocked by tricyclic inhibitors (acridine, phenothiazine, and their derivatives); 3 . the peripheral anionic site (Y72, Y124, W286) is located near the entrance of the gorge and is blocked by charged mono- or biquaternary inhibitors (edrophonium, propidium, decamethonium).

\subsection{Increased sensitivity towards insecticides by site-directed mutagenesis}

Shafferman et al. were able to generate a large number of recombinant human acetylcholinesterase (HuAChE) mutants for use in mechanistic studies. Amino acids were identified which are important for maintaining the structural integrity of the enzyme (Velan et al., 1991a; Shafferman et al., 1992a) as well as residues that are involved in catalysis and interaction with various substrates and reversible inhibitors (Shafferman et al., 1992b; Ordentlich et al., 1993; Ordentlich et al., 1996). The group also analysed the functional characteristics of the oxyanion hole in HuAChE (Ordentlich et al., 1998). Substitutions in the acyl pocket led to an increase in sensitivity of human AChE towards three tested organophosphate inhibitors (Ordentlich et al., 1996). Phenylalanine residues at position 295 and 297 were replaced by less bulky amino acids. The F295A mutant showed a 20-fold greater sensitivity towards paraoxon (Table 3). The introduction of valine at position 297 and leucine at position 297, in analogy to the corresponding positions in butyrylcholinesterase (BChE), led to a 25-fold increase in sensitivity to diisopropyl 
phosphorofluoridate (DFP). On the other hand, mutations of the hydrogen bond network residues Tyr-133, Glu-202, and Glu-450 led to a lower reactivity (up to a factor of 160) to paraoxon, DFP and diethyl phosphorofluoridate (DEFP). Modifications in the oxyanion hole (G122A and G121A) led to a decrease in sensitivity to DFP, DEFP, and paraoxon by up to three orders of magnitude (Ordentlich et al., 1998). The substitution of six aromatic amino acids in the active centre of human AChE by the corresponding amino acids of human BChE led to a 150-fold greater sensitivity to DFP (Kaplan et al., 2001). The bimolecular rate constant (ki) of the hexamutant, which expresses the overall potency of an irreversible inhibitor to inhibit AChE (Figure 1), was similar to the value obtained with human BChE. This increase in reactivity was the result of the space-creating replacements in the acyl pocket and of the replacements in the peripheral anionic site (PAS).

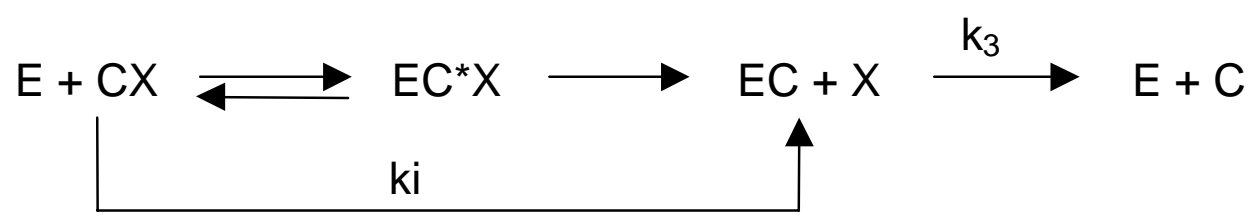

Figure 1: Inhibition mechanism of AChE (Aldridge, 1950); $\mathrm{E}=$ enzyme, $\mathrm{CX}=$ carbamate or organophosphate compound, $\mathrm{X}=$ leaving group, $\mathrm{C}=$ remaining group, $\mathrm{k}_{3}=$ decarbamylation rate constant and $\mathrm{ki}=$ bimolecular rate constant.

The influence of AChE mutants on the development of insecticide resistance in insect pest species has been extensively studied. A large number of DmAChE mutants was generated by changing 13 positions lining the gorge at the choline binding site, the peripheral anionic site, the acyl pocket, and at amino acid positions Y408 and Y409, which play a role in intramolecular signal transduction (Villatte et al., 2000). The analysis of sensitivity of these enzymes to several carbamate and organophosphate insecticides showed that the majority of amino acid replacements led to a lower sensitivity. Some mutations, e.g. F368L, led to a lower sensitivity to propoxur and to 
an increased sensitivity to naled, for example. This change in sensitivity varied considerably: F368S led to a 110-fold decrease in sensitivity to propoxur and to a 2.5-fold greater sensitivity to cis-chlorfenvenfos. There were, however, three Drosophila mutants which displayed a greater sensitivity to most tested organophosphates and carbamates. These include DmY408F, DmE107Y and DmY412A (Table 3). DmY408F is involved in the stabilisation of the insecticide molecule in the active site by exerting aromatic interactions. It has been suggested that DmE107Y and DmY412A may be part of the peripheral anionic site. Moreover, the substitution of tyrosine by phenylalanine at position 408 led to a mutant which was more sensitive to 12 out of 19 tested insecticides than the wild type (Villatte et al., 1998).

Boublik et al. have generated several tens of single and multiple DmAChE mutants and found various amino acid replacements that led to a greater sensitivity to insecticides (Boublik et al., 2002). The greatest improvement was observed for the sensitivity to dichlorvos for which a combined mutant (DmE69Y, DmY71D) was 300fold more sensitive than the Drosophila wild-type enzyme. Montesinos et al. have determined the bimolecular rate constants of seven different DmAChE mutants for methamidophos (Montesinos et al., 2000). The most sensitive mutant displayed a ki value of $2.2 \times 10^{6} \mathrm{M}^{-1} \mathrm{~min}^{-1}$; the wild type DmAChE only reached a ki value of $7.3 \mathrm{x}$ $10^{3} \mathrm{M}^{-1} \mathrm{~min}^{-1}$.

The protein-inhibitor interactions were studied by computer-aided molecular modelling techniques. The protein structure of RbAChE was modelled from the sequence based on the X-ray structure of the homologous Torpedo californica AChE (Figure 2). The inhibitors paraoxon and aldicarb were docked to the active site of RbAChE and the effect of mutations on specificity was predicted. According to these 
studies, Pleiss et al. replaced the acyl pocket residue phenylalanine-295 of rat brain AChE by leucine (Pleiss et al., 1997; Pleiss et al., 1999). The RbF295L mutation led to a greater sensitivity to all five tested organophosphates and the three tested carbamates. The increase in sensitivity was most pronounced for the bulky ethoprophos (factor of 80). This greater sensitivity was attributed to the enlarged acyl pocket.

To summarise, it can be concluded that mutations, which lead to a greater sensitivity to organophosphates or carbamates are not restricted to a special region of the AChE gorge. Some mutations were found in the acyl pocket, the peripheral anionic site or the choline-binding site of AChE. Most of these mutations were not created with the purpose of producing more sensitive AChE variants for application in biosensors. Instead, they were the result of mechanistic studies on the catalytic reaction with respect to enzyme and insecticide resistance. Most of these mutants were tested with model analytes like paraoxon and DFP and not with organophosphates or carbamates with a low bimolecular rate constant, which cannot yet be detected with AChE-biosensors at the required concentration range (e.g. aldicarb, ethiofencarb, butocarboxim or profenophos).

\section{Biosensor application of recombinant AChE}

Recently, the specific features of recombinant AChEs described have received greater attention in biosensor applications. Andrescu et al. used recombinant DmAChE for the oriented immobilization on nickel-modified thickfilm electrodes via a His-tag (Andreescu et al., 2001). The enzyme was genetically modified in order to incorporate six histidine residues at the position of the glycolipid anchor. In vivo, this 
anchor links the enzyme to the cytoplastic membrane. The immobilization of the enzyme had only a minor influence on the enzyme's activity. This approach allows the control of the enzyme's orientation. Thus, the preservation of the active site on the sensor surface can be optimised. Recombinant human AChE, expressed in Pichia pastoris, was used in combination with electric eel AChE in a newly-developed AChE-biosensor test for the sensitive detection of pesticides in infant food (Schulze et al., in press). The use of a special electrode treatment procedure made it possible to detect trace concentrations of organophosphates and carbamates in real food samples. The advantage of engineering proteins with enhanced sensitivity was shown by Montesinos et al. (Montesinos et al., 2000) who used DmAChE variants, which displayed a greater sensitivity to methamidophos. One of the seven tested mutants was able to decrease the detectable methamidophos concentration to a value as low as $1.4 \mu \mathrm{g} / \mathrm{L}$. In contrast, $4.8 \mu \mathrm{g} / \mathrm{L}$ were achieved with the wild type DmAChE and $53 \mu \mathrm{g} / \mathrm{L}$ with electric eel AChE.

A severe drawback of all methods that are based on the use of a single AChE form only, arises from the observation that each organophosphate and carbamate inhibits the enzyme to a different extent. This renders it virtually impossible to calibrate an unknown mixture of various analytes (of unknown/different concentrations). For example, the inhibition constants for individual organophosphates and carbamates against bovine erythrocyte AChE vary up to a factor of 500 (Herzsprung et al., 1989). In practice, paraoxon is generally used for calibration. However, the value of these procedures for assays involving AChE inhibitors of unknown composition raises doubts. On the other hand, all biosensors described so far are based on this mechanism. They provide a sum parameter as signal, which is expressed as total anti-acetylcholinesterase activity. To escape this dilemma, engineered variants of DmAChE as biological receptors of AChE-multisensors for the simultaneous 
detection and discrimination of binary mixtures of cholinesterase-inhibiting insecticides are becoming popular. Bachmann et al. combined three geneticallyengineered DmAChE mutants and wild type DmAChE in a multisensor format for the multianalyte detection of organophosphates and carbamates (Bachmann and Schmid, 1999; Bachmann et al., 2000). The DmAChE variants were selected from a large number of mutants on the basis of displaying an individual sensitivity pattern towards the target analytes. These systems are based on the combination of amperometric multielectrode biosensors with chemometric data analysis of sensor outputs using artificial neural networks. This type of multisensor enabled the quantitative discrimination of paraoxon and carbofuran with a resolution error of 0.4 $\mu \mathrm{g} / \mathrm{L}$ for paraoxon and $0.5 \mu \mathrm{g} / \mathrm{L}$ for carbofuran. A lower determination limit of $0.5 \mu \mathrm{g} / \mathrm{L}$ for each analyte $\left(1.8 \times 10^{-9} \mathrm{M}\right.$ paraoxon, respectively $2.3 \times 10^{-9} \mathrm{M}$ carbofuran) could be achieved by incorporating mutant DmY408F, which was designed for sensitive insecticide detection by site-directed mutagenesis.

\section{Conclusion}

At present, the application of the AChE inhibition test is restricted to only a limited number of analytes because AChE sensitivity to other analytes does not yet meet the standards of sensitivity required. Protein engineering will certainly become increasingly important in the development of biosensors. It is the most promising technique with respect to the design of $\mathrm{AChE}$ biosensors that meet the required standards. More sensitive AChE variants and sophisticated multianalyte detection systems are critical issues when it comes to turning AChE biosensors into marketable products. 


\section{Acknowledgement}

The authors thank Dr. Jürgen Pleiss for providing the model of rat brain AChE. 
Table 1: Biosensors for the detection of organophosphates and carbamates

\begin{tabular}{|c|c|c|c|c|}
\hline Enzyme source & Additional enzymes & Transducer & Detection limit & Reference \\
\hline $\begin{array}{l}\text { EeAChE (c.a.) or } \\
\text { HsBChE (c.a.) }\end{array}$ & & amperometric & $1.5 \mu \mathrm{g} / \mathrm{L}$ paraoxon & $\begin{array}{l}\text { (Skladal and } \\
\text { Mascini, } \\
\text { 1992) }\end{array}$ \\
\hline $\begin{array}{l}\text { EeAChE (c.a.) or } \\
\text { HsBChE (c.a.) }\end{array}$ & & amperometric & $3 \mu \mathrm{g} / \mathrm{L}$ paraoxon & $\begin{array}{l}\text { (Hart et al., } \\
\text { 1997) }\end{array}$ \\
\hline EeAchE (c.a.) & & amperometric FIA & $0.3 \mu \mathrm{g} / \mathrm{L}$ paraoxon & $\begin{array}{l}\text { (Jeanty and } \\
\text { Marty, 1997) }\end{array}$ \\
\hline EeAchE (c.a.) & choline oxidase (c.a.) & amperometric & $0.2 \mu \mathrm{g} / \mathrm{L}$ carbofuran & $\begin{array}{l}\text { (Cagnini et } \\
\text { al., 1995) }\end{array}$ \\
\hline EeAchE (c.a.) & choline oxidase (c.a.) & amperometric & $2 \mu \mathrm{g} / \mathrm{L}$ carbofuran & $\begin{array}{l}\text { (Palchetti et } \\
\text { al., 1997) }\end{array}$ \\
\hline EeAchE (c.a.) & choline oxidase (c.a.) & $\begin{array}{l}\text { potentiometric } \\
\text { Pt microelectrode }\end{array}$ & $\begin{array}{l}52 \mu \mathrm{g} / \mathrm{L} \text { choline } \\
73 \mu \mathrm{g} / \mathrm{L} \text { acetylcholine }\end{array}$ & $\begin{array}{l}\text { (Huang et } \\
\text { al., 1993) }\end{array}$ \\
\hline EeAchE (c.a.) & & $\begin{array}{l}\text { potentiometric } \\
\text { FIA }\end{array}$ & $25 \mu \mathrm{g} / \mathrm{L}$ paraoxon & $\begin{array}{l}\text { (Kumaran } \\
\text { and Tran- } \\
\text { Minh, 1992) }\end{array}$ \\
\hline EeAchE (c.a.) & & piezoelectric & $14 \mu \mathrm{g} / \mathrm{L}$ paraoxon & $\begin{array}{l}\text { (Abad et al., } \\
\text { 1998) }\end{array}$ \\
\hline $\begin{array}{l}\text { DmAChE (rec. WT and } \\
\text { mutants/baculovirus) }\end{array}$ & & amperometric & $0.5 \mu \mathrm{g} / \mathrm{L}$ paraoxon & $\begin{array}{l}\text { (Bachmann } \\
\text { et al., 2000) }\end{array}$ \\
\hline BeAChE (c.a.) & & amperometric FIA & $3 \mu \mathrm{g} / \mathrm{L}$ paraoxon & $\begin{array}{l}\text { (Günther } \\
\text { and } \\
\text { Bilitewski, } \\
\text { 1995) }\end{array}$ \\
\hline BeAChE (c.a.) & & amperometric FIA & $0.5 \mu \mathrm{g} / \mathrm{L}$ diazinon & $\begin{array}{l}\text { (Evtugyn et } \\
\text { al., 1999) }\end{array}$ \\
\hline BeAChE (c.a.) & choline oxidase (c.a.) & amperometric FIA & $0.5 \mu \mathrm{g} / \mathrm{L}$ carbofuran & $\begin{array}{l}\text { (Kindervater } \\
\text { et al., 1990) }\end{array}$ \\
\hline BChE (c.a.) & $\begin{array}{l}\text { choline oxidase (c.a.) } \\
\text { peroxidase (c.a.) }\end{array}$ & $\begin{array}{l}\text { potentiometric } \mathrm{pH} \\
\text { electrode }\end{array}$ & $0.05 \mathrm{ng} / \mathrm{L}$ trichlorphon & $\begin{array}{l}\text { (Ghindilis et } \\
\text { al., 1996) }\end{array}$ \\
\hline $\begin{array}{l}\text { Organophosphorus } \\
\text { hydrolase (rec. E.coli) }\end{array}$ & & amperometric & $25 \mu \mathrm{g} / \mathrm{L}$ paraoxon & $\begin{array}{l}\text { (Mulchanda } \\
\text { ni et al., } \\
\text { 1999a) }\end{array}$ \\
\hline $\begin{array}{l}\text { Organophosphorus } \\
\text { hydrolase (rec. E.coli) }\end{array}$ & & amperometric & $6 \mu \mathrm{g} / \mathrm{L}$ paraoxon & $\begin{array}{l}\text { (Mulchanda } \\
\text { ni et al., } \\
\text { 2001) }\end{array}$ \\
\hline $\begin{array}{l}\text { Organophosphorus } \\
\text { hydrolase (rec. E.coli) }\end{array}$ & & $\begin{array}{l}\text { potentiometric } \mathrm{pH} \\
\text { electrode }\end{array}$ & $550 \mu \mathrm{g} / \mathrm{L}$ paraoxon & $\begin{array}{l}\text { (Mulchanda } \\
\text { ni et al., } \\
\text { 1999b) }\end{array}$ \\
\hline $\begin{array}{l}\text { Organophosphorus } \\
\text { hydrolase (rec. E.coli) }\end{array}$ & & potentiometric & $1375 \mu \mathrm{g} / \mathrm{L}$ paraoxon & $\begin{array}{l}\text { (Gäberlein } \\
\text { et al., 2000) }\end{array}$ \\
\hline
\end{tabular}


Table 2: Expression levels of various AChEs in different expression systems

\begin{tabular}{|c|c|c|c|c|}
\hline \multirow{2}{*}{$\begin{array}{l}\text { Expression } \\
\text { system }\end{array}$} & \multirow{2}{*}{$\begin{array}{l}\text { Origin of } \\
\text { AChE }\end{array}$} & \multicolumn{2}{|c|}{ Yield $^{a}$} & \multirow[t]{2}{*}{ Reference } \\
\hline & & Activity & $\begin{array}{l}\text { Specific Activity } \\
{[\mathrm{U} / \mathrm{mg}]}\end{array}$ & \\
\hline HEK 293 & human & $150 \mathrm{U} / 10^{6}$ cells $^{\mathrm{D}}$ & 6000 & $\begin{array}{c}\text { (Kronman et al., } \\
\text { 1992) }\end{array}$ \\
\hline $\begin{array}{l}\text { Baculovirus } \\
\text { system }\end{array}$ & rat brain & $23 \mathrm{U} / \mathrm{mL}$ & n.i. & $\begin{array}{c}\text { (Mionetto et al., } \\
1997)\end{array}$ \\
\hline E. coli & human & n.i. & 2289 & $\begin{array}{c}\text { (Fischer et al., } \\
\text { 1993) }\end{array}$ \\
\hline $\begin{array}{l}\text { Transgenic } \\
\text { Tomato plant }\end{array}$ & human & $0.1 \mathrm{U} / \mathrm{mg}$ leaves & $\begin{array}{l}0.025 \text { (leaves) } \\
0.25 \text { (fruits) }\end{array}$ & $\begin{array}{c}\text { (Mor et al., } \\
\text { 2001) }\end{array}$ \\
\hline P. pastoris & $\begin{array}{l}\text { Nippostrongylus } \\
\text { brasiliensis }\end{array}$ & $\begin{array}{l}72 \mathrm{U} / \mathrm{mL}^{\mathrm{c}} \\
{[35 \mathrm{mg} / \mathrm{L}]}\end{array}$ & 2080 & $\begin{array}{c}\text { (Hussein et al., } \\
\text { 1999) }\end{array}$ \\
\hline
\end{tabular}

${ }^{\mathrm{a}}$ Calculated from data given by the authors, ${ }^{\mathrm{b}} 24 \mathrm{~h},{ }^{\mathrm{c}}$ Continuous culture for 7 days; n.i.: not indicated 
Table 3: Bimolecular rate constants $\left(\times 10^{-4} \mathrm{M}^{-1} \mathrm{~min}^{-1}\right)$ of various AChEs towards insecticides

\begin{tabular}{|c|c|c|c|c|c|c|c|c|}
\hline & Paraoxon & DFP & DEFP & $\begin{array}{l}\text { Paraoxon- } \\
\text { methyl }\end{array}$ & Carbaryl & $\begin{array}{l}\text { Methamid- } \\
\text { ophos }\end{array}$ & Ethoprophos & Reference \\
\hline WT Hu & 97 & 14 & 40 & & & & & $\begin{array}{l}\text { (Ordentlich } \\
\text { et al., 1996) }\end{array}$ \\
\hline Hu F295A & 1800 & 65 & 830 & & & & & $\begin{array}{l}\text { (Ordentlich } \\
\text { et al., 1996) }\end{array}$ \\
\hline Hu F295L & 800 & 264 & 940 & & & & & $\begin{array}{l}\text { (Ordentlich } \\
\text { et al., 1996) }\end{array}$ \\
\hline $\begin{array}{l}\text { Hu F295L/ } \\
\text { F297V }\end{array}$ & 117 & 340 & 310 & & & & & $\begin{array}{l}\text { (Ordentlich } \\
\text { et al., 1996) }\end{array}$ \\
\hline Hu E405A & 1.9 & 0.09 & 1.5 & & & & & $\begin{array}{l}\text { (Ordentlich } \\
\text { et al., 1996) }\end{array}$ \\
\hline Hu G121A & 0.085 & 0.007 & & & & & & $\begin{array}{l}\text { (Ordentlich } \\
\text { et al., 1998) }\end{array}$ \\
\hline $\begin{array}{l}\text { HuY72N/Y1 } \\
\text { 24Q/W286 } \\
\text { A/F295L/F2 } \\
\text { 97V/Y337A }\end{array}$ & & 1500 & & & & & & $\begin{array}{l}\text { (Kaplan et } \\
\text { al., 2001) }\end{array}$ \\
\hline $\begin{array}{l}\text { WT } \\
\text { HuBChE }\end{array}$ & & 1700 & & & & & & $\begin{array}{l}\text { (Kaplan et } \\
\text { al., 2001) }\end{array}$ \\
\hline WT Dm & 140 & & & 42 & 17 & 0.73 & & $\begin{array}{l}\text { (Montesinos } \\
\text { et al., 2000) }\end{array}$ \\
\hline Dm Y408F & 320 & & & 15 & 200 & & & $\begin{array}{l}\text { (Villatte et } \\
\text { al., 1998) }\end{array}$ \\
\hline Dm E107Y & 520 & & & 150 & 37 & & & $\begin{array}{l}\text { (Villatte et } \\
\text { al., 1998) }\end{array}$ \\
\hline Dm B08 & & & & & & 220 & & $\begin{array}{l}\text { (Montesinos } \\
\text { et al., 2000) }\end{array}$ \\
\hline WT Rb & 80 & & & 52 & & & 0.07 & $\begin{array}{l}\text { (Pleiss et } \\
\text { al., 1999) }\end{array}$ \\
\hline Rb F295L & 550 & & & 120 & & & 5.6 & $\begin{array}{l}\text { (Pleiss et } \\
\text { al., 1999) }\end{array}$ \\
\hline
\end{tabular}

WT: wild type; Hu: human AChE, amino acid numbering corresponds to human AChE; HuBChE: human butyrylcholinesterase; Dm: Drosophila melanogaster AChE, amino acid numbering corresponds to DmAChE; Rb: rat brain AChE, amino acid numbering corresponds to RbAChE. 


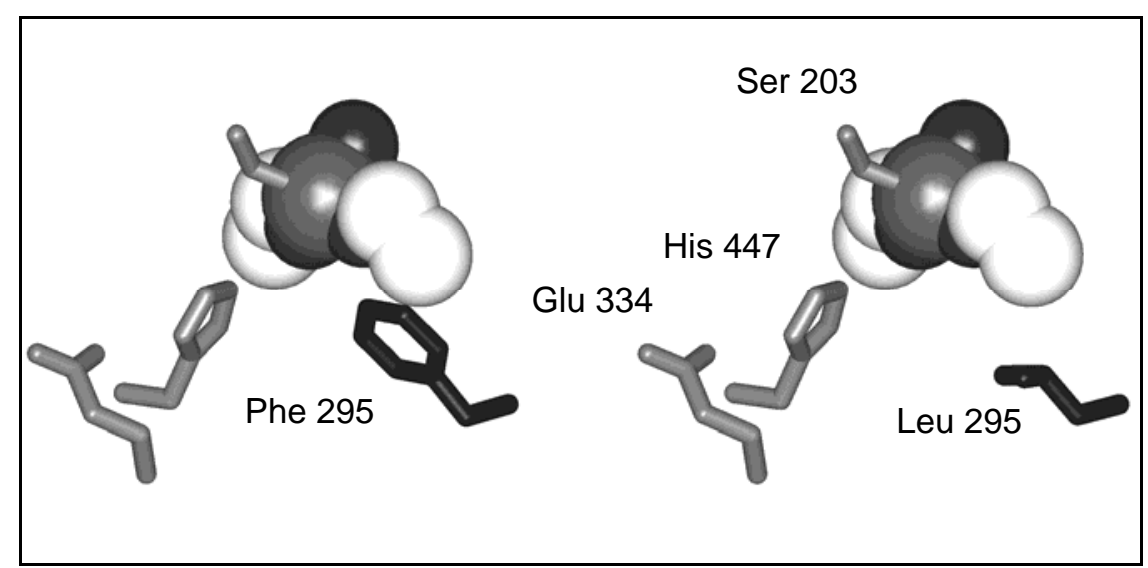

Figure 2: Complex of wild-type (left) and mutant (right) RbAChE with paraoxon. The catalytic triad (Ser203, His447, Glu334) and the mutation site are displayed in gray and black, respectively. 


\section{References}

Abad, J.M., Pariente, F., Hernandez, L., Abruna, H.D. and Lorenzo, E., 1998. Determination of organophosphorus and carbamate pesticides using piezoelectric biosensors. Analytical Chemistry 70, 2848-2855.

Aldridge, W.N., 1950. Some properties of specific acetylcholinesterase with particular reference to the mechanism of inhibition by diethyl p-nitrophenyl thiophosphate (E605) and analogues. Biochemical Journal 46, 451-456.

Andreescu, S., Magearu, V., Lougarre, A., Fournier, D. and Marty, J.-L., 2001. Immobilization of enzymes on sreen-printed sensors via an histidine tail. Application to the detection of pesticides using modified cholinesterase. Analytical Letters 34, 529-540.

Ashani, Y., Radic, Z., Tsigelny, I., Vellom, D.C., Pickering, N.A., Quinn, D.M., Doctor, B.P. and Taylor, P., 1995. Amino acid residues controlling reactivation of organophosphonyl conjugates of acetylcholinesterase by mono- and bisquaternary oximes. The Journal of Biological Chemistry 270, 6370-80.

Bachmann, T.T., Leca, B., Villatte, F., Marty, J.-L., Fournier, D. and Schmid, R.D., 2000. Improved multianalyte detection of organophosphates and carbamates with disposable multiresidue biosensors using recombinant mutants of Drosophila acetylcholinesterase and artificial neural networks. Biosensors \& Bioelectronics 15, 193-201.

Bachmann, T.T. and Schmid, R.D., 1999. A disposable, multielectrode biosensor for rapid simultaneous detection of the insecticides paraoxon and carbofuran at high resolution. Analytica Chimica Acta 401, 95-103.

Bazelyansky, M., Robey, E. and Kirsch, J.F., 1986. Fractional diffusion-limited component of reactions catalyzed by acetylcholinesterase. Biochemistry 25, 125-30.

Boublik, Y., Saint-Aguet, P., Lougarre, A., Arnaud, M., Villatte, F., Estrada-Mondaca, S. and Fournier, D., 2002. Acetylcholinesterase engineering for detection of insecticide residues. Protein Engineering 15, 43-50.

Cagnini, A., Palchetti, I., Lionti, I., Mascini, M. and Turner, A.P.F., 1995. Disposable ruthenized screen-printed biosensors for pesticide monitoring. Sensors and Actuators B 24-25, 85-89. 
Chaabihi, H., Fournier, D., Fedon, Y., Bossy, J.P., Ravallec, M., Devauchelle, G. and Cerutti, M., 1994. Biochemical characterization of Drosophila melanogaster acetylcholinesterase expressed by recombinant baculoviruses. Biochemical and Biophysical Research Communications 203, 734-742.

Cousin, X., Bon, S., Duval, N., Massoulie, J. and Bon, C., 1996a. Cloning and expression of acetylcholinesterase from Bungarus fasciatus venom. A new type of cooh-terminal domain; involvement of a positively charged residue in the peripheral site. The Journal of Biological Chemistry 271, 15099-108.

Cousin, X., Hotelier, T., Lievin, P., Toutant, J.P. and Chatonnet, A., 1996b. A cholinesterase genes server (ESTHER): A database of cholinesterase-related sequences for multiple alignments, phylogenetic relationships, mutations and structural data retrieval. Nucleic Acid Research 24, 132-136.

Coussen, F., Bonnerot, C. and Massoulie, J., 1995. Stable expression of acetylcholinesterase and associated collagenic subunits in transfected RBL cell lines: production of GPI-anchored dimers and collagen-tailed forms. European Journal of Cell Biology 67, 254-60.

Duval, N., Bon, S., Silman, I., Sussman, J.L. and Massoulie, J., 1992a. Site-directed mutagenesis of active-site-related residues in Torpedo acetylcholinesterase. Presence of a glutamic acid in the catalytic triad. FEBS Letters 309, 421-423.

Duval, N., Massoulie, J. and Bon, S., 1992b. H and T subunits of acetylcholinesterase from Torpedo, expressed in COS cells, generate all types of globular forms. The Journal of Cell Biology 118, 641-53.

Estrada-Mondaca, S. and Fournier, D., 1998. Stabilisation of recombinant Drosophila acetylcholinesterase. Protein Expression and Purification 12, 166.

Estrada-Mondaca, S., Lougarre, A. and Fournier, D., 1998. Drosophila acetylcholinesterase: effect of post-translational modifications on the production in the baculovirus system and substrate metabolization. Archives of Insect Biochemistry and Physiology 38, 84-90.

Evtugyn, G.A., Ivanov, A.N., Gogol, E.V., Marty, J.-L. and Budnikov, H.C., 1999. Amperometric flow-injection biosensor for the determination of cholinesterase inhibitors. Analytica Chimica Acta 385, 13-21.

Faerman, C., Ripoll, D., Bon, S., Le Feuvre, Y., Morel, N., Massoulie, J., Sussman, J.L. and Silman, I., 1996. Site-directed mutants designed to test back-door hypotheses of acetylcholinesterase function. FEBS Letters 386, 65-71. 
Fischer, M., Ittah, A., Liefer, I. and Gorecki, M., 1993. Expression and reconstitution of biologically active human acetylcholinesterase from Escherichia coli. Cellular and Molecular Neurobiology 13, 25-38.

Gäberlein, S., Knoll, M., Spener, F. and Zaborosch, C., 2000. Disposable potentiometric enzyme sensor for direct determination of organophosphorus insecticides. Analyst 125, 2274-2279.

Ghindilis, A.L., Morzunova, H.C., Barmin, A.V. and Kurochkin, I.N., 1996. Potentiometric biosensors for cholinesterase inhibitor analysis based on mediatorless bioelctrocatalysis. Biosensors \& Bioelectronics 11, 837-880.

Gibson, K. and Guilbault, G.G., 1975. A Potentiometric Assay of Cholinesterase. Analytica Chimica Acta 76, 245-251.

Guilbault, G.G. and Das, J., 1970. Immobilization of Cholinesterase and Urease. Analytical Biochemistry 33, 341-355.

Guilbault, G.G. and Iwase, A., 1976. Assay of Cholinesterase in an Electrode System with an Immobilized Substrate. Analytica Chimica Acta 85, 295-300.

Guilbault, G.G. and Kramer, D.N., 1965. Fluorometric System Employing Immobilized Cholinesterase for Assaying Anticholinesterase Compounds. Analytical Chemistry 37, 1675-1680.

Guilbault, G.G., Kuan, S.S., Tully, J. and Hackney, D., 1970a. New Procedure for Rapid and Sensitive Detection of Cholinesterase Separated by Polyacrylamide Gel Electrophoresis. Analytical Biochemistry 36, 72-77.

Guilbault, G.G., Sadar, M.H., Kuan, S.S. and Casey, D., 1970b. Effect of Pesticides on Liver Cholinesterases from Rabbit, Pigeon, Chicken, Sheep and Pig. Analytica Chimica Acta 51, 83-93.

Guilbault, G.G., Sadar, M.H., Kuan, S.S. and Casey, D., 1970c. Enzymatic Methods of Analysis. Trace Analysis of various Pesticides with Insect Cholinesterase. Analytica Chimica Acta 52, 75-82.

Guilbault, G.G. and Schmid, R.D., 1991. In: Turner, A.P.F., Yevdokimov, Y.M. (Eds.) Advances in Biosensors 1. Electrochemical, Piezoelectric and Fibre-Optic Biosensors. p. 257-289.

Günther, A. and Bilitewski, U., 1995. Characterisation of inhibitors of acetylcholinesterase by an automated amperometric flow-injection system. Analytica Chimica Acta 300, 117-125. 
Harel, M., Kryger, G., Rosenberry, T.L., Mallender, T.L., Fletcher, R.J., Guss, J.M., Silman, I. and Sussman, J.L., 2000. Three-dimensional structure of Drosophila melanogaster acetylcholinesterase and of its complexes with two potent inhibitors. Protein Science 9, 1063-1072.

Hart, A.L., Collier, W.A. and Janssen, D., 1997. The response of screen-printed enzyme electrodes containing cholinesterases to organophosphates in solution and from commercial formulations. Biosensors \& Bioelectronics 12 , 645-654.

Heim, J., Schmidt-Dannert, C., Atomi, H. and Schmid, R.D., 1998. Functional expression of a mammalian acetylcholinesterase in Pichia pastoris: Comparison to acetylcholinesterase, expressed and reconstituted from Escherichia coli. Biochimica Biophysica Acta 1396, 306-319.

Herzsprung, P., Weil, L. and Quentin, K., 1989. Bestimmung von Phosphorpestiziden und insektiziden Carbamaten mittels Cholinesterasehemmung; Mitt. 1: Hemmwirkung von Phosphorpestiziden und insektiziden Carbamaten auf immobilisierte Cholinesterase. Zeitschrift Wasser-Abwasser-Forschung 22, 6772.

Huang, Z., Villarta-Snow, R., Lubrano, G.J. and Guilbault, G.G., 1993. Development of Choline and Acetylcholine Pt Microelectrodes. Analytical Biochemistry 215, 31-37.

Hussein, A.S., Chacon, M.R., Smith, A.M., Tosado-Acevedo, R. and Selkirk, M.E., 1999. Cloning, Expression, and Properties of a Nonneuronal Secreted Acetylcholinesterase from the Parasitic Nematode Nippostrongylus brasiliensis. The Journal of Biological Chemistry 274, 9312-9319.

Hussein, A.S., Smith, A.M., Chacon, M.R. and Selkirk, M.E., 2000. Determinants of substrate specificity of a second non-neuronal secreted acetylcholinesterase from the parasitic nematode Nippostrongylus brasiliensis. European Journal of Biochemistry 267, 2276-2282.

Jeanty, G. and Marty, J.-L., 1997. Detection of paraoxon by continuous flow system based enzyme sensor. Biosensors \& Bioelectronics 13, 213-218.

Kaplan, D., Ordentlich, A., Barak, D., Ariel, N., Kronman, C., Velan, B. and Shafferman, A., 2001. Does "Butyrylization" of Acetylcholinesterase through Substitution of the Six Divergent Aromatic Amino Acids in the Active Center 
Gorge Generate an Enzyme Mimic of Butyrylcholinesterase? Biochemistry 40, 7433-7445.

Kindervater, R., Künnecke, W. and Schmid, R.D., 1990. Exchangeable immobilized enzyme reactor for enzyme inhibition tests in flow-injection analysis using a magnetic device. Determination of pesticides in drinking water. Analytica Chimica Acta 234, 113-117.

Kronman, C., Velan, B., Gozes, Y., Leitner, M., Flashner, Y., Lazar, A., Marcus, D., Sery, T., Papier, Y., Grosfeld, H. and et al., 1992. Production and secretion of high levels of recombinant human acetylcholinesterase in cultured cell lines: microheterogeneity of the catalytic subunit. Gene 121, 295-304.

Kumaran, S. and Tran-Minh, C., 1992. Determination of Organophosphorous and Carbamate Insecticides by Flow Injection Analysis. Analytical Biochemistry 200, 187-194.

Legay, C., Bon, S. and Massoulie, J., 1993. Expression of a cDNA encoding the glycolipid-anchored form of rat acetylcholinesterase. FEBS Lett 315, 163-6.

Martinez, C.R., Gonzales, R.E., Moran, A.M.J. and Mendez, H.J., 1992. Sensitive method for the determination of organophosphorus pesticides in fruits and surface waters by high-performance liquid chromatography with ultraviolet detection. Journal of Chromatography 607, 37-45.

Massoulie, J. and Bon, S., 1976. Affinity chromatography of acetylcholinesterase. The importance of hydrophobic interactions. European Journal of Biochemistry 68, 531-539.

Millard, C.B. and Broomfield, C.A., 1995. Anticholinesterases: medical applications of neurochemical principles. Journal of Neurochemistry 64, 1909-18.

Mionetto, N., Morel, N., Massoulie, J. and Schmid, R.D., 1997. Biochemical determination of insecticides via cholinesterases. 1. Acetylcholinesterase from rat brain: functional expression using a baculovirus system, and biochemical characterization. Biotechnol Tech 11, 805-812.

Montesinos, T., Perez-Munguia, S., Marty, J.-L. and Mitsubayashi, K., 2000. Screenprinted electrodes, with genetically modified cholinesterase, for detection of pesticides in water-miscible organic solvent. Journal of Advanced Science 12, 217-222. 
Mor, T.S., Sternfeld, M., Soreq, H., Arntzen, C.J. and Mason, H.S., 2001. Expression of recombinant human acetylcholinesterase in transgenic tomato plants. Biotechnology and Bioengineering 75, 259-66.

Morel, N. and Massoulie, J., 1997. Expression and processing of vertebrate acetylcholinesterase in the yeast Pichia pastoris. Biochemical Journal 328, 121-129.

Morel, N. and Massoulie, J., 2000. Comparative expression of homologous proteins. A novel mode of transcriptional regulation by the coding sequence folding compatibility of chimeras. The Journal of Biological Chemistry 275, 7304-12.

Mulchandani, A., Mulchandani, P. and Chen, W., 1999a. Amperometric Thick-Film Strip Electrodes for Monitoring Organophosphate Nerve Agents Based on Immobilized Organophosphorus Hydrolase. Analytical Chemistry 71, 22462249.

Mulchandani, P., Chen, W. and Mulchandani, A., 2001. Flow Injection Amperometric Enzyme Biosensor for Direct Determination of Organophosphate Nerve Agents. Environmental Science \& Technology 35, 2562-2565.

Mulchandani, P., Mulchandani, A., Kaneva, I. and Chen, W., 1999b. Biosensor for direct determination of organophosphate nerve agents. 1. Potentiometric enzyme electrode. Biosensors \& Bioelectronics 14, 77-85.

Ordentlich, A., Barak, D., Kronman, C., Ariel, N., Segall, Y., Velan, B. and Shafferman, A., 1996. The Architecture of Human Acetylcholinesterase Active center Probed by Interactions with Selected Organophosphate Inhibitors. The Journal of Biological Chemistry 271, 11953-11962.

Ordentlich, A., Barak, D., Kronman, C., Ariel, N., Segall, Y., Velan, B. and Shafferman, A., 1998. Functional Characteristics of the Oxyanion Hole in Human Acetylcholinesterase. The Journal of Biological Chemistry 273, 1950919517.

Ordentlich, A., Barak, D., Kronman, C., Flashner, Y., Leitner, M., Segall, Y., Ariel, N., Cohen, S., Velan, B. and Shafferman, A., 1993. Dissection of the human acetylcholinesterase active center determinants of substrate specificity. Identification of residues constituting the anionic site, the hydrophobic site, and the acyl pocket. The Journal of Biological Chemistry 268, 17083-17095. 
Palchetti, I., Cagnini, A., Carlo, M.D., Coppi, C., Mascini, M. and Turner, A.P.F., 1997. Determination of pesticides in real samples using a disposable biosensor. Analytica Chimica Acta 337, 315-321.

Pleiss, J., Mionetto, N. and Schmid, R.D., 1997. Protein engineering of rat brain acetylcholinesterase: a point mutation enhances sensitivity to pesticides. Protein Engineering 10 (Suppl.), 66.

Pleiss, J., Mionetto, N. and Schmid, R.D., 1999. Probing the acyl binding site of acetylcholinesterase by protein engineering. Journal of Molecular Catalyis B: Enzymatic 6, 287-296.

Pylypiw, H.M., 1993. Rapid Gas Chromatographic Method for the Multiresidue Screening of Fruits and Vegetables for Organochlorine and Organophosphate Pesticides. Journal of AOAC International 76, 1369-1373.

Radic, Z., Gibney, G., Kawamoto, S., MacPhee-Quigley, K., Bongiorno, C. and Taylor, P., 1992. Expression of recombinant acetylcholinesterase in a baculovirus system: kinetic properties of glutamate 199 mutants. Biochemistry 31, 9760-7.

Radic, Z., Pickering, N.A., Vellom, D.C., Camp, S. and Taylor, P., 1993. Three distinct domains in the cholinesterase molecule confer selectivity for acetyland butyrylcholinesterase inhibitors. Biochemistry 32, 12074-12084.

Ralston, J.S., Main, A.R., Kilpatrick, B.F. and Chasson, A.L., 1983. Use of procainamide gels in the purification of human and horse serum cholinesterase. Biochemical Journal 211, 243-250.

Rosenberry, T.L., 1975. Acetylcholinesterase. Advances in Enzymology and Related Areas of Molecular Biology 43, 103-218.

Rosenberry, T.L. and Scoggin, D.M., 1984. Structure of human erythrocyte acetylcholinesterase. The Journal of Biological Chemistry 259, 5643-5652.

Saxena, A., Redman, A.M., Jiang, X., Lockridge, O. and Doctor, B.P., 1997. Differences in active site gorge dimension of cholinesterase revealed by binding of inhibitors to human butyrylcholinesterase. Biochemistry 36, 1464214651.

Schulze, H., Scherbaum, E., Anastassiades, M., Vorlová, S., Schmid, R.D. and Bachmann, T.T., in press. Development, validation, and application of an acetylcholinesterase-biosensor test for the direct detection of insecticide residues in infant food. Biosensors \& Bioelectronics. 
Shafferman, A., Kronman, C., Flashner, Y., Leitner, M., Grosfeld, H., Ordentlich, A., Gozes, Y., Cohen, S., Ariel, N., Barak, D., Harel, M., Silman, I., Sussman, J.L. and Velan, B., 1992a. Mutagenesis of Human Acetylcholinesterase. The Journal of Biological Chemistry 267, 17640-17648.

Shafferman, A., Velan, B., Ordentlich, A., Kronman, C., Grosfeld, H., Leitner, M., Flashner, Y., Cohen, S., Barak, D. and Ariel, N., 1992b. Substrate inhibition of acetylcholinesterase: residues affecting signal transduction from the surface to the catalytic center. EMBO Journal 11, 3561-3568.

Simon, S. and Massoulie, J., 1997. Cloning and expression of acetylcholinesterase from Electrophorus. Splicing pattern of the 3' exons in vivo and in transfected mammalian cells. The Journal of Biological Chemistry 272, 33045-55.

Skladal, P. and Mascini, P., 1992. Sensitive detection of pesticides using amperometric sensors based on cobalt phthalocyanine-modified composite electrodes and immobilized cholinesterases. Biosensors \& Bioelectronics 7 , 335-343.

Sussman, J.L., Harel, M., Frolow, F., Oeffner, C., Goldman, A., Toker, L. and Silman, I., 1991. Atomic structure of acetylcholinesterase from Torpedo californica: a prototypic acetylcholinesterase-binding protein. Science 253, 872-879.

Van Sant, M.J., 1986. Applications of the Piezoelectric Crystal Detector in Environmental Analysis. PhD Thesis Thesis, University of New Orleans.

Velan, B., Grosfeld, H., Kronman, C., Leitner, M., Gozes, Y., Lazar, A., Flashner, Y., Markus, D., Cohen, S. and Shafferman, A., 1991a. The Effect of Elimination of Intersubunit Disulfide Bonds on the Activity, Assembly, and Secretion of Recombinant Human Acetylcholinesterase. The Journal of Biological Chemistry 266, 23977-23984.

Velan, B., Kronman, C., Grosfeld, H., Leitner, M., Gozes, Y., Flashner, Y., Sery, T., Cohen, S., Ben-Aziz, R., Seidman, S. and et al., 1991b. Recombinant human acetylcholinesterase is secreted from transiently transfected 293 cells as a soluble globular enzyme. Cellular and Molecular Neurobiology 11, 143-56.

Vellom, D.C., Radic, Z., Li, Y., Pickering, N.A., Camp, S. and Taylor, P., 1993. Amino acid residues controlling acetylcholinesterase and butyrylcholinesterase specificity. Biochemistry 32, 12-7. 
Villatte, F., Bachmann, T.T., Hussein, A.S. and Schmid, R.D., 2001. Acetylcholinesterase assay for rapid expression screening in liquid and solid media. Biotechniques 30, 81-4, 86.

Villatte, F., Marcel, V., Estrada-Mondaca, S. and Fournier, D., 1998. Engineering sensitive acetylcholinesterase for detection of organophosphate and carbamate insecticides. Biosensors \& Bioelectronics 13, 157-164.

Villatte, F., Ziliani, P., Marcel, V., Menozzi, P. and Fournier, D., 2000. A high number of mutations in insect acetylcholinesterase may provide insecticide resistance. Pesticide Biochemistry and Physiology 67, 95-102.

von Storp, L.H. and Guilbault, G.G., 1972. A New Assay for Cholinesterase Potentiometric Determinations in Flow Streams. Analytica Chimica Acta 62, 425-430. 